\title{
EFFECT OF ORGANIC FERTILIZATION METHOD ON RICE CROP YIELD AND QUALITY
}

\author{
Bahnas, O.T.** and Solaf S. Abd El-Reheem* \\ ABSTRACT
}

This study was carried out at El-Helaly Village, El-Dakhlia Governorate, during 2015 summer season to identify the effect of organic fertilization method on rice crop yield and quality. The experiment was established and designed statistically as a split plots with three replications. The main plots involved tillage treatment levels of moldboard plough followed by disc harrow, rotary plough as a minimum tillage and chisel plough (two perpendicular passes) followed by disc harrow. The sub plots included wheat straw application forms levels of wheat stubble and chopped wheat straw. The results indicated that the rotary plough accompanied with chopped wheat straw accomplished higher actual field capacity of $0.92 \mathrm{fed} / \mathrm{h}$, lower specific energy requirements of 25.43 MJ/fed, lower seed drill wheel skidding of $2.55 \%$ and higher plant distribution uniformity of 94\%. While, the moldboard plough followed by disc harrow and accompanied with chopped wheat straw achieved more desirable soil characteristics and higher rice grain yield of $4.36 \mathrm{Mg} / \mathrm{fed}$. So, it is recommended to apply the moldboard plough followed by disc harrow and accompanied with chopped wheat straw as a proper organic fertilization method.

\section{INTRODUCTION}

$\sqrt{ }$ heat straw is the agricultural by-product obtained from different parts of wheat plant like stem, leaves etc. It is rich in cellulosic fibers (33.70-40.00\%), hemicelluloses (21-26\%), crude protein (3.60\%), lignin (11-22\%) and ash (7-9\%) which make wheat straw as most important and balanced substrate for microbial cultures for its diverse applications in fermentation, food, feed, medicine industries and in fields to increase soil fertility (Yasin et al., 2010 and Khan and Mubeen, 2012).

** Head of Researcher at the Ag. Eng. Res. Inst. (AEnRI), Giza.

* Researcher at the Ag. Eng. Res. Inst. (AEnRI), Giza. 
In Egypt, wheat straw is a major feed source for ruminants. Mechanical harvest leaves wheat straw in field as such. It reduces the availability of straw to livestock, which is already in short supply by about $40 \%$. Wheat straw disposal is considered as a major problem facing the egyptian farmers who exert effortless to burn straw to prepare the soil for next crop, causing a serious phenomenon of ground and air pollution.

Wheat straw is helpful in maintaining the soil fertility if added as such or by mixing with the urea to balance the nitrogen content in the soil (Yadvinder-Singh et al., 2004). The potential benefits of shallow incorporation of residues shortly after wheat harvest include accelerated aerobic decomposition of straw that increases $\mathrm{N}$ immobilization and mineralization, reduces $\mathrm{ch}_{4}$ emission and enhances release of allelopathic or phenolic compounds in the soil (Blanco-Canqui and Lal, 2009).

On the other hand, tillage assists to incorporate wheat straw into the soil, pulverizes soil aggregates and exposes humus which facilitates decomposition of soil organic matter by soil organisms (Zhu et al., 2011).

the past few decades, chemical fertilizers have widely spread throughout the world. The excessive and continuous chemical fertilization occurs an accumulated side effects on the human and the animal health, pollutes the environment, declines the crop yield and maximizes the production costs (Savci, 2012).

Recently, there is a great attention is directed to minimize chemical fertilizers application (Pan et al., 2009 and Morteza et al., 2011).

In view of these points, the present study was undertaken to identify effect of some organic fertilization methods using wheat straw on rice crop yield and quality.

\section{MATERIAL AND METHODS}

\section{Experimental site and soil characteristics:}

During 2015 summer season, a field experiment of 1 feddan $(70$ x 60 m)was carried out at El-Helaly village, El-Dakhlia Governorate, wheres the preseeding crop was of Sakha 69 variety wheat wich was harvested using a reciprocating mower, achieving mean crop yield of 3.64 and $2.84 \mathrm{Mg}$ grains and straw/fed, respectively. According to El-Serafy and El- 
Ghamry (2006), tables (1), (2) and (3) presented soil mechanical analysis, some soil characteristics, and some wheat straw characteristics, respectively.

Table (1): Soil mechanical analysis of the experimental site.

\begin{tabular}{|c|c|c|c|c|c|c|}
\hline \multirow{2}{*}{$\begin{array}{l}\text { Soil layer } \\
\text { depth, } \mathrm{m}\end{array}$} & \multicolumn{3}{|c|}{ Sand, \% } & \multirow{2}{*}{ Silt, \% } & \multirow{2}{*}{$\begin{array}{c}\text { Clay, } \\
\%\end{array}$} & \multirow{2}{*}{$\begin{array}{c}\text { Soil texture } \\
\text { class }\end{array}$} \\
\hline & coarse, $\%$ & fine, $\%$ & total, $\%$ & & & \\
\hline $0-0.10$ & 2.50 & 9.85 & 12.35 & 37.10 & 50.55 & $\begin{array}{c}\text { Silty clay } \\
\text { loam }\end{array}$ \\
\hline $0.10-0.20$ & 1.79 & 9.82 & 11.61 & 39.12 & 49.27 & $\begin{array}{c}\text { Silty clay } \\
\text { loam }\end{array}$ \\
\hline $0.20-0.30$ & 1.20 & 9.10 & 10.30 & 40.50 & 49.20 & $\begin{array}{l}\text { Silty clay } \\
\text { loam }\end{array}$ \\
\hline
\end{tabular}

Table (2): Some soil characteristics of the experimental site.

\begin{tabular}{|c|c|c|c|c|c|c|c|}
\hline $\begin{array}{c}\text { Soil layer } \\
\text { depth, } \mathrm{m}\end{array}$ & $\begin{array}{c}\text { Moisture } \\
\text { content } \\
\text { (d.b.), } \%\end{array}$ & $\begin{array}{c}\text { Bulk } \\
\text { density, } \\
\text { g/ } \mathrm{cm}^{3}\end{array}$ & $\begin{array}{c}\text { Organic } \\
\text { carbon, } \\
\%\end{array}$ & $\begin{array}{c}\mathrm{pH}, \\
1: 2.5\end{array}$ & $\begin{array}{c}\text { AVAILABLE } \\
\text { N, ppm }\end{array}$ & $\begin{array}{c}\text { Available } \\
\text { P, ppm }\end{array}$ & K, ppm \\
\hline $0-0.10$ & 18.12 & 1.59 & 1.55 & 7.85 & 27.55 & 14.44 & 321.29 \\
\hline $0.10-0.20$ & 19.56 & 1.53 & 1.43 & 7.70 & 25.70 & 14.05 & 320.67 \\
\hline $0.20-0.30$ & 19.94 & 1.49 & 1.35 & 7.68 & 25.06 & 13.86 & 319.55 \\
\hline
\end{tabular}

Table (3): Some characteristics of wheat straw.

\begin{tabular}{|c|c|c|c|c|c|c|c|}
\hline $\begin{array}{c}\text { Moisture } \\
\text { content (d. } \\
\text { b.), } \%\end{array}$ & $\begin{array}{c}\text { Ash, } \\
\%\end{array}$ & $\begin{array}{c}\text { Organic } \\
\text { matter, } \\
\%\end{array}$ & $\begin{array}{c}\text { Organic } \\
\text { carbon, } \\
\%\end{array}$ & $\begin{array}{c}\text { Total N, } \\
\%\end{array}$ & $\begin{array}{c}\text { Total P, } \\
\%\end{array}$ & $\begin{array}{c}\text { Total K, } \\
\%\end{array}$ & C/N ratio \\
\hline 8.08 & 13.21 & 73.51 & 42.96 & 0.89 & 0.58 & 2.05 & $42.9: 0.896$ \\
\hline
\end{tabular}

\section{Agricultural practices:}

\section{Wheat straw application:}

The following wheat straw forms were applied:

1. Wheat stubble $\left(315\right.$ stubblle $\left./ \mathrm{m}^{2}\right)$ of $0.15 \mathrm{~m}$ height upon soil surface which was left after harvest by raising the mower cutter bar at the suitable height.

2. Chopped wheat straw of $15-40 \mathrm{~mm}$ length which was collected after wheat threshing and manually broadcasted uniformly upon soil surface with a rate of $350 \mathrm{~kg} / \mathrm{fed}$ as cited by El-Maddah and Badr (2005). 


\section{Tillage:}

The following tillage systems were conducted:

1. Moldboard tillage was conducted at $0.25 \mathrm{~m}$ depth usin a three bottoms moldboard plough of $0.82 \mathrm{~m}$ ploughing width. The secondary tillage was achieved at $0.10 \mathrm{~m}$ depth using a tandem disc harrow of $3.30 \mathrm{~m}$ total width. It consists of four disc groups, two groups of notched discs of 0.57 $\mathrm{m}$ diameter in the front and two groups of completed disc edge of $0.59 \mathrm{~m}$ diameter in the rear. The disc spacing in each group is $0.23 \mathrm{~m}$

2. Minimum tillage was conducted at $0.10 \mathrm{~m}$ depth using a rotary plough of $24 \mathrm{~L}$-shape blades which are arranged on the total machine width (1.55 $\mathrm{m})$. It was operated at rotary speed of $145 \mathrm{rpm}(2.41 \mathrm{~m} / \mathrm{s}$ peripheral speed $)$ which was obtained by operating the tractor PTO at a speed of $540 \mathrm{rpm}$, and adjusting the gearbox position.

3. Conventional tillage was employed in 2 perpendicular directions at $0.15 \mathrm{~m}$ depth using a seven shanks chisel plough. The single point shares are arranged in two rows (three shares on the front row and four on the rear row. The distance between two consecutive shares is $0.25 \mathrm{~m}$. The secondary tillage was accomplished using the previous tandem disc harrow. The previous tillage machines were operated using a 2 WD tractor of $45 \mathrm{~kW}$ power at $3.85 \mathrm{~km} / \mathrm{h}$ forward speed for moldboard, rotary and chisel ploughs and at $4.50 \mathrm{~km} / \mathrm{h}$ forward speed for disc harrow.

\section{Precision land leveling:}

The precision land leveling was carried out at 0 slope using a mounted hydraulic land leveler of $1.26 \mathrm{~m}^{3}$ capacity $(0.60 \times 3.00 \times 070 \mathrm{~m})$ which was accompanied with a laser control equipment that consists of transmitter (Spectra-physics 1145 laserplane), control box (CB2MTD), receiver mast, receiver unit and telescoping grade rod (1084 English). The precision land leveling unit was operated using a $4 \mathrm{WD}$ tractor of $90 \mathrm{~kW}$ power at $4.25 \mathrm{~km} / \mathrm{h}$ forward speed.

\section{Nitrogen fertilization:}

The mineral Nitrogen fertilizer in the form of Yuria $(46 \% \mathrm{~N})$ with a rate of $69 \mathrm{~kg} \mathrm{~N} / \mathrm{fed}$. was applied in four equal doses. An activated dose was applied before sowing and the others were applied 20, 40 and 60 days after sowing. 


\section{Planting:}

A mounted seed drill of 21 rows with $0.15 \mathrm{~m}$ row spacing was used to drill $60 \mathrm{~kg}$ selected seeds/fed of Giza 178 rice variety. It was operated at $4.00 \mathrm{~km} / \mathrm{h}$ forward speed using a $2 \mathrm{WD}$ tractor of $45 \mathrm{~kW}$ power.

The tillage and planting implement operating speeds were achieved by selecting appropriate gears, adjusting tractor engine throttle at the maximum position at adjusting the engine speed around $85 \%$.

All other practices were done according to the recommendations of Rice Res. Dept., Field Crops Res. Inst., Agric. Res. Center, Ministry of Agriculture and Land Reclamation (2015).

\section{Treatments and statistical design:}

During the experiment the following treatments were tested:

1. Tillage treatment: It included levels of rotary plough as a minimum tillage, moldboard plough followed by disc harrow and chisel plough (two perpendicular passes) followed by disc harrow.

2. Wheat straw application form treatment: It included levels of wheat stubble and chopped wheat straw.

The experiment was established and designed statistically as a split plots with three replications. The main plots involved tillage treatment levels and the sub plots included wheat straw application form treatment levels.

\section{Measurements:}

\section{Implement performance:}

1. Implement actual field capacity $(A F C)$ :

It is determined as cited by Srivastava et al. (2006)as follows: $A F C=\frac{1}{A T T}, \mathrm{fed} / \mathrm{h}$

Where: $A T T$ is the actual total time required for acting one fed, hrs.

2. Soil mean weight diameter $(M W D)$ :

According to Dimoyiannis (2009), soil samples were taken $48 \mathrm{hrs}$ after sowing irrigation using a sampler box of $0.50 \times 0.20 \times 0.20 \mathrm{~m}$. The soil crumbles were sieved using a set of sieves of 2, 5, 10, 20, 50 and $100 \mathrm{~mm}$ mesh whole diameters. The MWD is determined as follows: 
$M W D=\frac{1}{w} \times(2 A+5 B+10 C+20 D+50 E+100 F), \mathrm{mm}$

Where: $A+V+\ldots+G$ is weight of separated soil by the set, $\mathrm{kg}$.

$W=A+\mathrm{B}+\mathrm{C}+\mathrm{D}+\mathrm{E}+\mathrm{F}, \mathrm{kg}$.

3. Implement specific energy requirements:

As cited by ASAE (2003), the auxiliary tractor of $82.8 \mathrm{~kW}$ power pulled the tractor-drawn tillage machine combination. The draught force is measured as the horizontal component of the force between the driving tractor and the tractor -machine combination using a spring dynamometer. The average dynamometer readings are determined when the auxiliary tractor and the tractor-machine combination are moving in sequence on the experimental soil surface. The traction force required for the tillage machine is estimated as the difference between the dynamometer reading and the pulling resistance of the $45 \mathrm{~kW}$ tractor which is estimated by pulling the tractor alone on the experimental soil surface. Then, the power required $(P)$ for operating the tillage machine is calculated as follows:

$P=3.61 \times$ TF $x S \times 0.85$, MJ

Where: 3.61 is coefficient of changing from kW.h to MJ.

$T F$ is traction force, $\mathrm{kN}$.

$T F=S_{w} \times \vartheta, k N . \mathrm{P}=\frac{T F x S}{c}$

$S_{w}$ is specific work, $\mathrm{kN} . \mathrm{m} / \mathrm{m} 3$.

$\vartheta$ is volume of tilled soil, $\mathrm{m}^{3}$.

$S$ is actual tractor forward speed, $\mathrm{m} / \mathrm{s}$.

Specific energy requirements $=\frac{P o}{A F C} \times 100, \mathrm{MJ} . \mathrm{h} / \mathrm{fed}$

According to Ismail (2007), the equivalent PTO power is estimated as follows:

Equivalent $\mathrm{PTO}$ power $=\frac{P x 3.61 x 0.85}{0.80}, \mathrm{MJ}$

0.80 is PTO loading per the maximum tractor PTO power.

Specific energy requirements $=\frac{\text { equivalent } P \text { TO power }}{A F C}, \mathrm{MJ} . \mathrm{h} / \mathrm{fed}(6)$

Seed drill wheel skidding $(s k)$ : 
It is determined as cited by Srivastava et al. (2006) as follows:

$$
s k=\frac{L-3.14 D}{L} \times 100, \%
$$

Where: $L$ is the actual distance per one seed drill wheel revolution, $\mathrm{m}$.

$D$ is the diameter of the seed drill wheel, $\mathrm{m}$.

Plant distribution uniformity:

As cited by ASAE (2004), the plant distribution uniformity is estimated as the coefficient of variation (c.v.) from average number of plants at unit area in longitudinal direction as follows:

$c v=\frac{\sigma_{n}}{S_{r}} \times 100, \%$

Where: $\sigma_{n}$ is standard deviation of seed spacing along the same row, $\mathrm{m}$.

$S_{r}$ is recommended seed spacing along the same row, $\mathrm{m}$.

\section{Soil characteristics:}

At harvest, soil samples were collected from each plot at 0-0.10, 0.100.20 and $0.20-0.30 \mathrm{~m}$ layers. As cited by El-Serafy and El-Ghamry (2006), the soil organic carbon, the soil $\mathrm{pH}$ and the available soil macronutrients concentration were determined.

\section{Rice crop yield and yield components:}

At harvest, across each experimental unit, an area of $1 \mathrm{~m}^{2}$ is taken randomly to determine rice crop yield and yield components. Then, rice yield is calculated on basis of $14 \%$ moisture content (d.b.).

\section{Statistical Analysis:}

SPSS (Version 20.0) computer software package is used to employ the analysis of variance test and the LSD tests for rice crop yield data.

\section{Regression and Correlation Analysis:}

Microsoft Excel 2010 computer software is used to employ the simple regression and correlation analysis to represent the relation between rice crop yield and soil mean weight diameter.

\section{RESULTS AND DISCUSSION}

\section{Machinery Performance:}

Table (4) demonstrates that the rotary plough accompanied with chopped wheat straw accomplished higher actual field capacity of $0.92 \mathrm{fed} / \mathrm{h}$. It is 
may be explained that the rotary plough creates an elemental leveled soil surface with one operation. While, the moldboard and the chisel ploughs achieve uneven soil surface, requiring a secondary tillage using the disc harrow, utilizing more time to prepare the seed bed.

The obtained soil mean weight diameter could be arranged as a ascending order: rotary system $<$ moldboard system $<$ chisel system. This trend may be illustrated that the rotary plough cuts, breaks down and throws up behind the soil, fulfilling an excessive soil pulverization. While the moldboard plough cuts, crumbles, lefts and turns the soil slice. Whilst, the chisel plough breaks up the soil without converting, realizing larger soil clods size.

The rotary plough expended the lower specific energy requirements of $25.43 \mathrm{MJ} / \mathrm{fed}$. This finding is due to the proportional of energy requirements with the tilled cross-sectional area. The shallow tillage of the rotary plough diminishes the normal loads on the tillage elements. This decreases the soil cutting and breaking down resistance and the friction forces between the soil and the tillage elements, expending lower draught.

Table (4): Machinery performance under wheat straw application forms.

\begin{tabular}{|c|c|c|c|c|c|c|c|c|c|c|}
\hline \multirow[t]{2}{*}{$\begin{array}{l}\text { Tillage } \\
\text { system }\end{array}$} & \multicolumn{2}{|c|}{$\begin{array}{l}\text { Actual } \\
\text { field } \\
\text { capacity, } \\
\text { fed/h }\end{array}$} & \multicolumn{2}{|c|}{$\begin{array}{c}\text { Soil } \\
\text { mean } \\
\text { weight } \\
\text { diameter, } \\
\text { mm }\end{array}$} & \multicolumn{2}{|c|}{$\begin{array}{c}\text { Specific } \\
\text { energy } \\
\text { requirements, } \\
\text { MJ/fed }\end{array}$} & \multicolumn{2}{|c|}{$\begin{array}{c}\text { Seed drill } \\
\text { wheel } \\
\text { skidding, } \\
\%\end{array}$} & \multicolumn{2}{|c|}{$\begin{array}{c}\text { Plant } \\
\text { distribution } \\
\text { uniformity, } \\
\%\end{array}$} \\
\hline & $\mathrm{a}$ & B & A & B & A & b & $\mathrm{a}$ & $\mathrm{b}$ & $\mathrm{a}$ & B \\
\hline $\begin{array}{l}\text { Moldboard } \\
\text { plough + disc } \\
\text { harrow }\end{array}$ & 0.70 & 0.75 & 89 & 84 & 67.85 & 64.74 & 4.75 & 3.80 & 90 & 92 \\
\hline $\begin{array}{l}\text { Rotary } \\
\text { plough }\end{array}$ & 0.88 & 0.92 & 42 & 46 & 28.58 & 25.43 & 3.12 & 2.55 & 91 & 94 \\
\hline $\begin{array}{l}\text { Chisel } \\
\text { plough } \\
\text { passes } \quad+ \\
\text { disc harrow }\end{array}$ & 0.64 & 0.67 & 98 & 93 & 54.85 & 52.95 & 4.90 & 3.80 & 87 & 90 \\
\hline
\end{tabular}

$\mathrm{a}$ is wheat stubble and $\mathrm{b}$ is chopped wheat straw. 
The rotary plough complemented the lower seed drill wheel skidding of $2.55 \%$. It is attributed to the seed drill stability upon the leveled surface that minimizes the seed drill vibration, resulting in higher contact area between the seed drill wheel and the soil surface. Consequently, higher plant distribution uniformity of $94 \%$ was accomplished using the rotary plough. It is due to the higher degree of soil pulverization that decreases the seed kinetic energy, resulting in lower seed rolling motion. Then, the accuracy of seed deposition increases.

Data in table (4) display that the wheat stubble accomplished unacceptable machinery performance. It is illustrated that the wheat stubble obstructs the machine and twines at the tillage elements, resulting in higher tractor wheel slip.

\section{Soil Characteristics:}

Through Figures (1) to (5), it is shown that the moldboard plough followed by disc harrow and accompanied with chopped wheat straw achieved more desirable soil characteristics at upper and deeper soil layers. It recorded higher soil organic carbon value of $2.90 \%$, lower soil $\mathrm{Ph}$ value of 7.39 and higher soil $\mathrm{N}, \mathrm{P}$ and $\mathrm{K}$ concentration values of 39, 19 and $349 \mathrm{ppm}$, respectively. This tendency may be explained that the moldboard plough accomplished moderate soil particles size. Then, the irrigation water streams, detaches soil particles from the surface and pushes fine particles into surface pores, creating smaller pores, offering greater resistance to gravity, where they can impede the infiltration process, resulting in lower value of soil salinity, enhancing the biological process in which microorganisms decompose the soil organic material, consuming oxygen and producing carbon dioxide, water and heat into the soil, releasing more amount of soil $\mathrm{N}, \mathrm{P}$ and $\mathrm{K}$.

While, the rotary plough achieved an excessive soil pulverization and created a loose structure that has enclosed soil particle arrangement. This structure has lower ability to keep the soil moisture content.

The chisel system achieved undesirable soil characteristics. This finding is due to the frequent vehicles traffic which increases the soil compaction that encloses the soil particles, resulting in decreasing the pore spaces.

It is clear that the soil organic carbon content at the surface soil layer is higher than that at the sub-surface layer. This finding could be attributed to the increase in the biological activity of the surface layer as a result of higher porosity, aeration and water retention. 


\section{0-0.10 m $\quad 0.10-0.20 \mathrm{~m} \quad 0.20-0.30 \mathrm{~m}$}

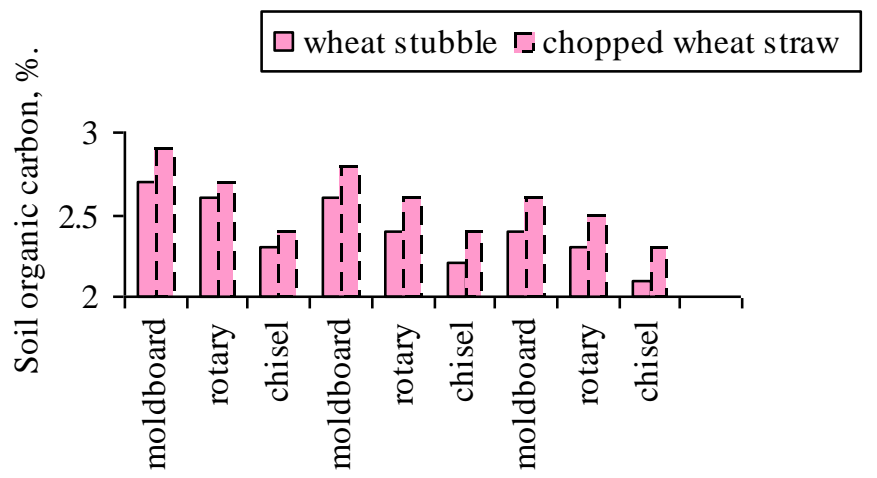

Fig. (1): Effect of organic fertilization method on soil organic carbon.

$$
\text { 0-0.10 m } \quad 0.10-0.20 \mathrm{~m} \quad 0.20-0.30 \mathrm{~m}
$$

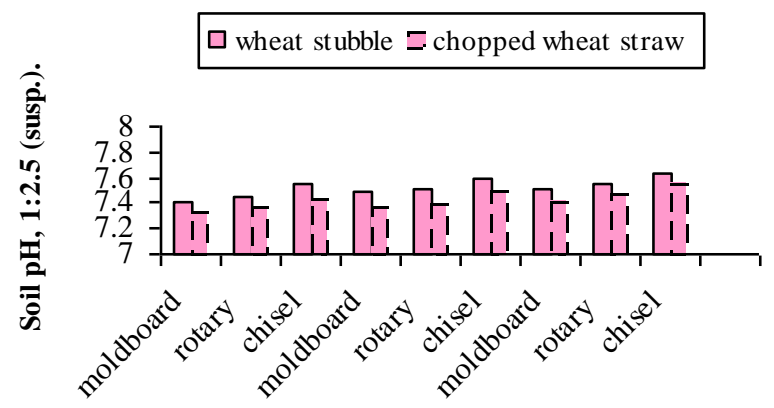

Fig. (2): Effect of organic fertilization method on soil $\mathrm{pH}$.

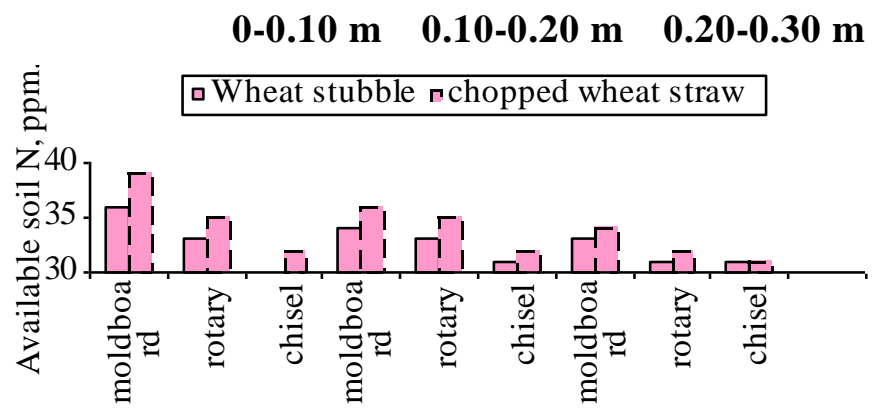

Fig. (3): Effect of organic fertilization method on available soil $\mathrm{N}$ concentration. 


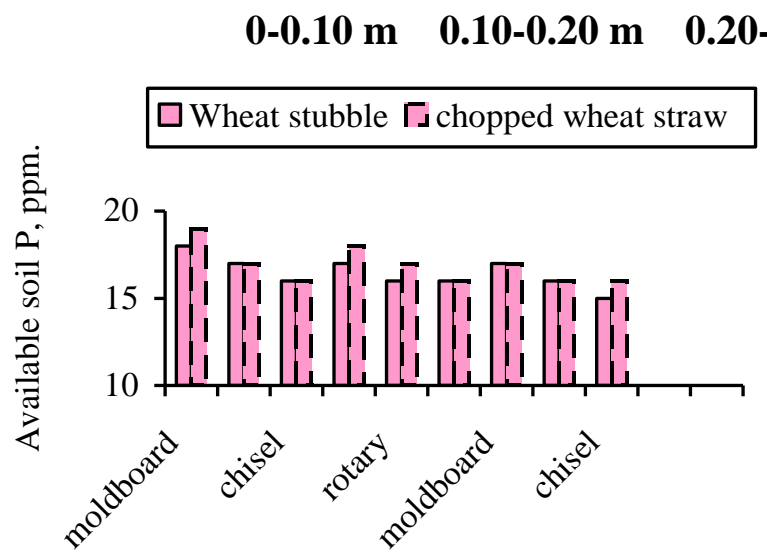

Fig. (4): Effect of organic fertilization method on available soil P concentration.

\section{0-0.10 m $\quad 0.10-0.20 \mathrm{~m} \quad 0.20-0.30 \mathrm{~m}$}

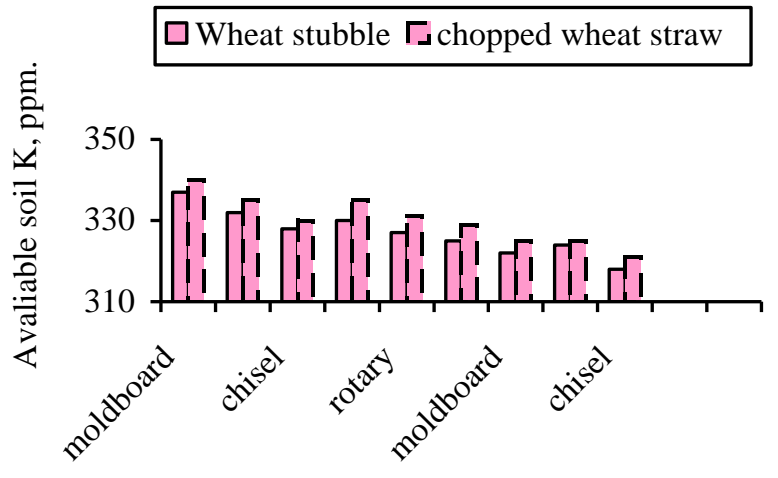

Fig. (5): Effect of organic fertilization method on available soil $\mathrm{K}$ concentration.

\section{Rice Crop Yield and Yield Components:}

Fig. (6) exhibits that applying moldboard plough followed by disc harrow and accompanied with chopped wheat straw achieved the higher rice yield values of $4.63 \mathrm{Mg} /$ fed grain and $5.12 \mathrm{Mg}$ /fed straw. Table (5) shows that it recorded the higher rice yield components values of $0.85 \mathrm{~m}$ plant length, 494 effective tillers number $/ \mathrm{m}^{2}, 0.25 \mathrm{~m}$ panicle length, 160 filled grains/panicle, $160 \mathrm{~g}$ panicle mass and $25 \mathrm{~g} 1000$ grains mass. This 
finding is due to the desirable soil characteristics as a result of using the moldboard plough. In addition, this result means that, the rice crop yield was affected significantly by the chopped wheat straw which improves the soil characteristics through organic matter decomposition by soil micro organisms.

The analysis of variance test indicated that there is a significant difference in rice grain yield due to tillage and wheat straw application treatments. LSD test at 0.05 level shows that the moldboard plough followed by disc harrow and accompanied with chopped wheat straw achieved higher rice crop yield among the other treatments.

The regression and correlation analysis revealed that there is a significant highly positive correlation between rice crop yield (y) and soil mean weight diameter $(\mathrm{x})$ as follows:

Wheat stubble:

Grain: $\mathrm{y}=-0.065 \mathrm{x}+4.273$

$\mathrm{R}^{2}=0.99$

Straw: $\mathrm{y}=-0.080 \mathrm{x}+4.897$

$\mathrm{R}^{2}=0.91$

Chopped wheat straw:

Grain: $y=-0.175 x+5.345$

$\mathrm{R}^{2}=0.99$

Straw: $y=-0.180 x+5.870$

$\mathrm{R}^{2}=0.91$

\section{wheat stubble chopped wheat straw}

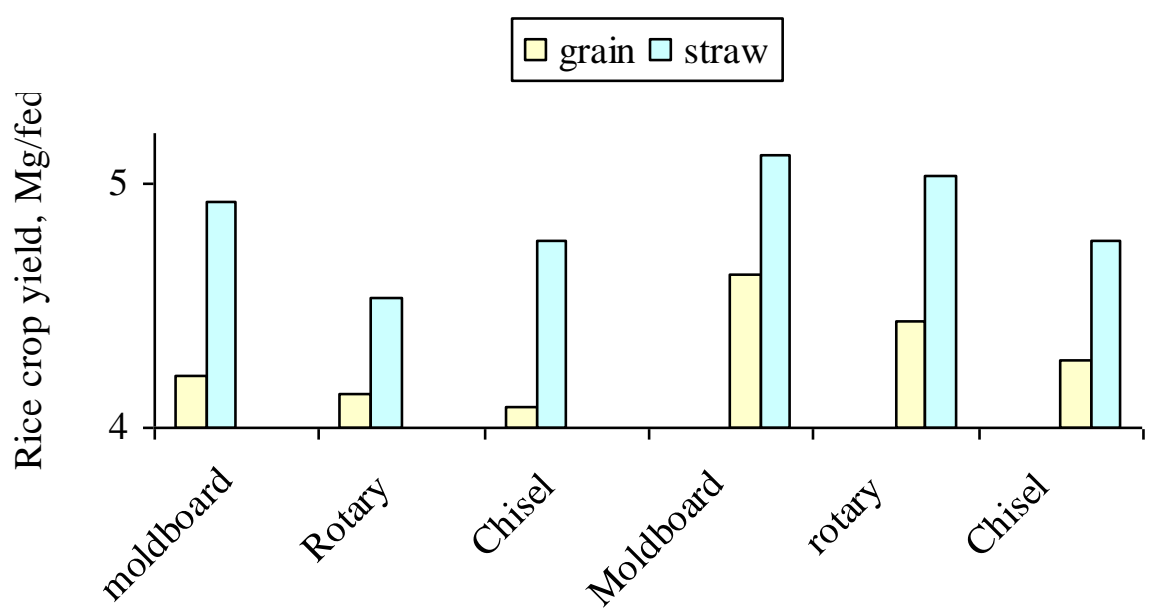

Fig. (6): Effect of organic fertilization method on rice crop yield. 
Table (5): Effect of organic fertilization method on rice yield components.

\begin{tabular}{|c|c|c|c|c|c|c|c|}
\hline $\begin{array}{l}\text { Tillage } \\
\text { system }\end{array}$ & $\begin{array}{c}\text { Wheat } \\
\text { straw } \\
\text { application } \\
\text { form }\end{array}$ & $\begin{array}{l}\text { Plant } \\
\text { length, } \\
\text { m. }\end{array}$ & $\begin{array}{c}\text { Effective } \\
\text { tillers } \\
\text { number } / \mathrm{m}^{2}\end{array}$ & $\begin{array}{c}\text { Panicle } \\
\text { length, } \\
\text { m }\end{array}$ & $\begin{array}{c}\text { Filled } \\
\text { grains/panicle }\end{array}$ & $\begin{array}{c}\text { panicle } \\
\text { mass, } \\
\text { g. }\end{array}$ & $\begin{array}{c}1000 \\
\text { grains } \\
\text { mass, } \\
\text { g. }\end{array}$ \\
\hline \multirow[b]{2}{*}{ Moldboard } & $\begin{array}{l}\text { Wheat } \\
\text { stubble }\end{array}$ & 0.83 & 486 & 0.23 & 156 & 3.26 & 22 \\
\hline & $\begin{array}{c}\text { Chopped } \\
\text { wheat } \\
\text { straw } \\
\end{array}$ & 0.85 & 494 & 0.25 & 160 & 3.30 & 25 \\
\hline \multirow[b]{2}{*}{ Rotary } & $\begin{array}{l}\text { Wheat } \\
\text { stubble }\end{array}$ & 0.83 & 484 & 0.23 & 154 & 3.24 & 21 \\
\hline & $\begin{array}{c}\text { Chopped } \\
\text { wheat } \\
\text { straw }\end{array}$ & 0.84 & 488 & 0.24 & 158 & 3.27 & 23 \\
\hline \multirow[b]{2}{*}{ Chisel } & $\begin{array}{c}\text { Wheat } \\
\text { stubble }\end{array}$ & 0.82 & 469 & 0.22 & 138 & 3.21 & 20 \\
\hline & $\begin{array}{c}\text { Chopped } \\
\text { wheat } \\
\text { straw }\end{array}$ & 0.83 & 477 & 0.23 & 145 & 3.23 & 22 \\
\hline
\end{tabular}

\section{CONCLUSION}

The obtained results of this study could be concluded as follows:

1. The rotary plough accomplished the higher acceptable performance among other tillage systems.

2. The rotary ploughing achieved the higher acceptable seed drill performance.

3. The moldboard plough followed by disc harrow achieved more desirable soil characteristics.

4. The moldboard plough followed by disc harrow and accompanied with chopped rice straw achieved higher rice grain yield of $4.63 \mathrm{Mg} / \mathrm{fed}$.

Finally, it is recommended to apply moldboard plough followed by disc harrow and accompanied with chopped wheat straw which complemented higher rice crop yield. 


\section{LITERATURE SITED}

ASAE Standards. 48 $^{\text {th }}$ Ed. (2003). Current standards for calculating tractor performance parameters including draft. ASAE D497.4 St. Joseph, MI.

ASAE Standards. 341.3 (2004). Procedure for measuring distribution uniformity and calibrating granular broadcasting spreader. ASAE standard book, 198-201.

Blanco-Canqui, H. and R. Lal (2009). Crop residue removal impacts on soil productivity and environmental quality. Critical Reviews in Plant Sci,. 28: 139-163.

Dimoyiannis, D. (2009). Seasonal soil aggregate stability variation in relation to rainfall and temperature under Mediterranean conditions. Earth Surfaces, Processes and Landforms, 34: 860-866.

El-Maddah, E.I. and S.E. Badr (2005). Effect of crop residuals filled moles on some physical and hydrophysical soil properties. J. Agric. Sci. Mansoura Univ., 30 (11): 7179-7204.

El-Serafy, Z.M. and A.M. El-Ghamry (2006). Methods of soil and water analysis (Practices). Soils Dept., Fac, Agric., Mansoura Univ., 253 pp (In Arabic).

Ismail, Z.I. (2007). Applied and theoretical fundamentals in seed-bed preparation implements. Part $12^{\text {nd }}$ Ed. Agric. Eng. Dept., Fac, Agric., Mansoura Univ., 298 pp (In Arabic).

Khan, T.S. and U. Mubeen (2012). Wheat straw: A pragmatic overview. J. of Biological Sci., 4 (6): 673-675.

Ministry of Agriculture and Land Reclamation (2015). The technical recommendations of rice.Agric. Res. Center. Field Crops Res. Inst, Rice program, 58 pp (In Arabic).

Morteza, S.; A. Nasiri and S.L. Laware (2011). Effect of organic fertilizer on growth and yield components in rice (Oryza sativa L.). J. Agric. Sci., 3 (3): 2-17. 
Pan, G.; P. Zhou; Z. Li; S. Pete; L. Li; D. Qiu; X. Zhang; X. Xu; S. Shen and $X$. Chen (2009). Combined inorganic/organic fertilization enhances $\mathrm{N}$ efficiency and increases rice productivity through organic carbon accumulation in a rice paddy from the Tai Lake region, China. Agric. Ecosyst. Environ., 131: 274-280.

Savci, S. (2012). Investigation of effect of chemical fertilizers on environment. APCBEE Procedia, 1: 287-292.

Srivastava, A.K.; C.E. Goering and R.P. Rohrbach (2006). Engineering principles of agricultural machines. $2^{\text {nd }}$ Ed. ASABE Pub. USA.

Yadvinder-Singh, C.S. Khind; O.P. Meelu and R.K. Gupta (2004). Long-term effects of organic inputs on yield and soil fertility in the rice-wheat rotation. Soil Sci. Soc. Am. J., 6 (8): 845-853.

Yasin, M.; A.W. Bhutto; A.A. Bazmi and S. Karim (2010). Efficient utilization of rice-wheat straw to produce value added composite products. Int. J. Chem. Env. Eng., 1 (2): 136-143.

Zhu, L.Q.; D.W. Zhang and X.M. Bian (2011). Effects of continuous returning straws to field and shifting different tillage methods on changes of physical-chemical properties of soil and yield components of rice. Chinese J. of Soil Sci., 42 (1): 81-85.

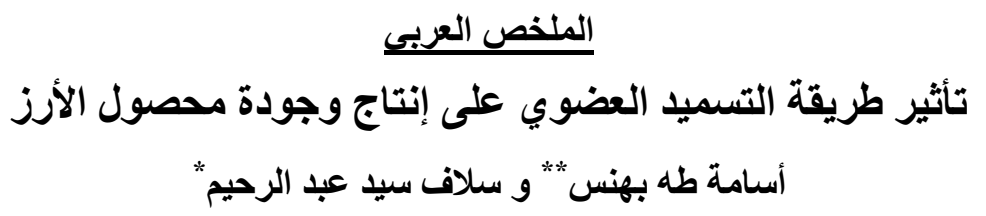

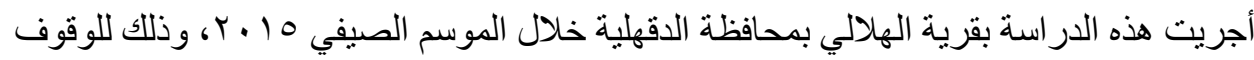

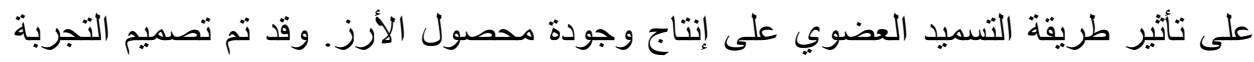

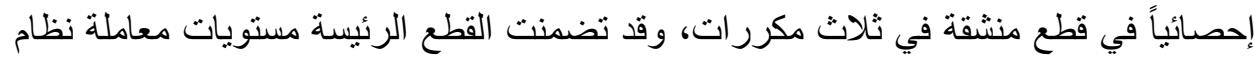

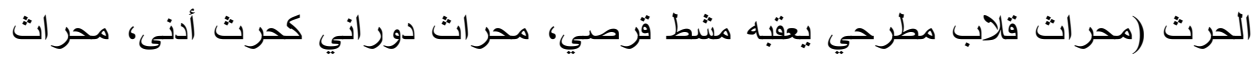

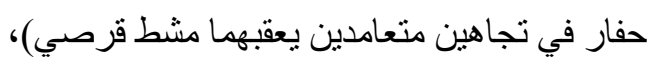

* * رئيس بحوث بمعهد بحوث الهندة الزراعية ـ مركز البحوث الزراعية ـ الجيزة.

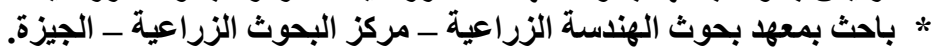


بينما إثتملت القطع الثقية على مستويات معاملة إستخدام تبن القمح كسماد عضوي (الجزء القداء

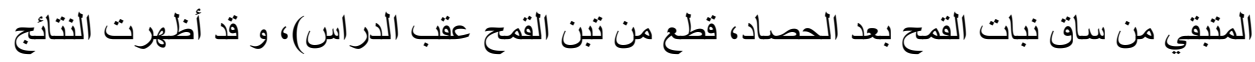

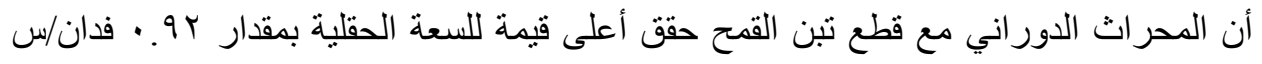

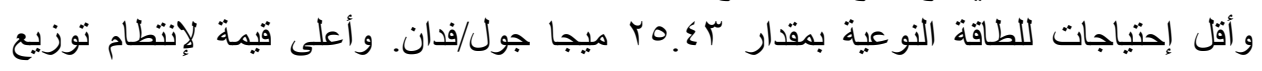

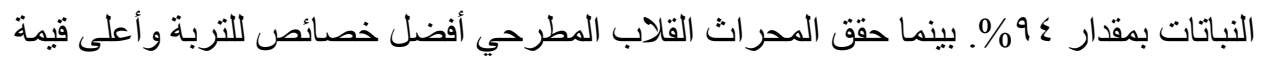

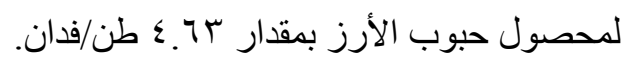

وبصفة عامة فإنه يوصى باستخدام المحراث القلاب المطرحي مع قطع من تبن القمح كطريقة للتسميد العضوي لتحقيق أعلى قيمة لمحصول بانئ لحبوب الأرز. 